\title{
An Investigation of Rural-Urban Students' Critical Thinking in Biology Across Gender
}

\author{
Badrud Tamam $^{1}$, Aloysius Duran Corebima ${ }^{2}$, Siti Zubaidah ${ }^{3}$, Endang Suarsini ${ }^{4}$ \\ 1 Malang State University, Biology Education Department, Malang, East Java Province, Indonesia Trunojoyo Madura \\ University, Science Education Study Program, Bangkalan, East Java Province, Indonesia, badruttamam@trunojoyo.ac.id \\ 2. Kanjuruhan Malang University, Study Program of Natural Science Education, Malang, Indonesia, \\ durancorebima@gmail.com \\ 3 Malang State University, Biology Education Department, Malang, East Java Province, Indonesia, \\ siti.zubaidah.fmipa@um.ac.id \\ 4 Malang State University, Biology Education Department, Malang, East Java Province, Indonesia, \\ endang.suarsini.fmipa@um.ac.id
}

Annotation. This study aimed to investigate the difference in rural-urban students' critical thinking in biology class across gender. It involved 289 students from public and private senior high schools. Essay tests were administered to measure the students' critical thinking skills. The study results showed that female students outperformed male students in critical thinking. Meanwhile, the rural students demonstrated better critical thinking skills than urban students.

Keywords: critical thinking skills, gender, rural schools, urban schools.

\section{Introduction}

The rapid technology and information advancement have affected the flow of information. Learners should be able to filter information to acquire the correct details of such information. In relation to this issue, the notion of critical thinking becomes prominent. According to Iman and Angraini (2019), critical thinking is required to analyze and evaluate information. As life problems grow more complex, every individual is forced to adapt and make the right decision to deal with the situation (Choi et al., 2011). Therefore, in this case, education should be able to equip students with the skills needed in the 21st century. Partnership for 21st century skills (2009) has formulated some skills that need 
to be mastered by students in the future. One of which is critical thinking. The emphasis on teaching critical thinking skills in school is necessary.

Critical thinking is the ability to think reflectively and consider what to believe and what to do (Ennis, 2011). According to Kaddoura (2011), critical thinking involves connecting and applying concepts through multi-logical thinking and considerations. Facione (1990) defines critical thinking as interpreting, analyzing, evaluating, infer, explaining, and performing a self-regulatory activity. Critical thinking is used to interpret and evaluate the results of observation, communication, and other sources of information (Che, 2002; Wang \& Zheng, 2016). Critical thinking encompasses various intellectual values, such as clarification, relevance, adequacy, constancy, and so on (Fisher, 2001). Critical thinking also involves higher cognitive processes in processing information to generate new thoughts (Choy \& Cheah, 2009).

Critical thinking is an essential competency for students (Bailin, 2002; Repo et al., 2017; Carter et al., 2017). Critical thinking is the primary goal in science learning (Dowd et al., 2018; Tiruneh et al., 2017; Larsson, 2017), including in biology learning. It has a strong correlation with student's academic achievement (Carter et al., 2017) and success and affects students in the long run (Fong et al., 2017). Critical thinking plays a crucial role in fulfilling society's personal, social, and professional needs that always experience changes (Che, 2002; Zubaidah et al., 2015; McCormick et al., 2015). Through critical thinking, one can see something comprehensively and evaluate it to survive the global era (Che, 2002). Shakirova (2007) claims that critical thinking helps an individual handle various social, scientific, and practical problems effectively.

Ennis (1996) mentions six basic elements in critical thinking. First, F (Focus); that is associated with focusing on a question or an issue to decide what is believed. Second, $\mathrm{R}$ (Reason); that recognizes the reasons that support or reject decisions based on relevant situations and facts. Third, I (Inference); that is to draw a reasonable or convincing conclusion. Fourth, S (Situation); that is to understand a situation and always maintain a thinking situation to help clarify questions being asked and recognize key terms and relevant parts as a supporting element. Fifth, $\mathrm{C}$ (Clarity), which explains the meaning of terms that are being used. Sixth, O (Overview), which is to review and analyze the decision made thoroughly.

Some studies conducted in Indonesia show that students have not been empowered to think critically (Hasan et al., 2013; Corebima, 2016). In fact, many Indonesian students have poor performance in critical thinking (Subiantoro \& Fatkurrahman, 2009; Sulasih et al., 2017). Masita et al. (2016) found that the average score of students' critical thinking was categorized as low (34.2). The students' poor performance in critical thinking resulted from learning dominated by conventional methods (Hasan et al., 2013). The classroom condition does not allow the students to engage in critical thinking actively, and they are not allowed to hone their critical thinking skills (Khan, 2008).

Both internal and external factors influence critical thinking. Internal factors that can affect critical thinking include self-determination, intelligence, emotional state, positive 
self-image, personality traits, and cognitive abilities (Sternberg, 2002). Another important internal factor that affects critical thinking is gender (Mortellaro, 2015; Mawaddah et al., 2018). The difference between males' and females' brain structure has been acknowledged (Kimura \& Harshman, 1984; Zaidi, 2010; Ruigrok et al., 2014). Gender difference leads to distinguished cognitive and neurobiological mechanisms (Wassell et al., 2015). Mawaddah et al. (2018) argue that gender creates psychological and physiological differences between male and female students.

Besides critical thinking, gender has been identified as one of the determinants of student academic success. Gender issues are important matters that need to be overcome because learning should not only benefit one particular side. Male and female students need to have the same opportunity to achieve success. For the last ten decades, gender inequality has been a significant issue in Indonesia. According to the Human Development Report 2018, the index of gender inequality in Indonesia was placed in the 116th position out of 189 countries. Meanwhile, the World Bank (2012) has declared that one of the ultimate goals of development is gender equality.

Gender inequality is reflected in student's achievement in science. Gender inequality in science can be explained by socio-cultural aspects and stereotypes (Hill et al., 2010). There is little information on how individual factors can explain gender equality. Wood (2008) states that females' way of speaking and statements are very detailed, showing the depth of connection, while male speech characteristics are more likely to the point, especially in giving advice or solutions. Men and women have cognitive differences that result from the complex relationships of nature and nurture (Halpern et al., 2007). Moreover, Halpern et al. (2007) have noted that women are apt to have better verbal abilities than men, whereas men are superior in manipulating visual objects and symbols.

Research on gender-critical thinking skills, in general, has been widely reported. However, investigation on the role of gender in critical thinking is still lacking. A study by Arslan (2012) and Mahanal (2012) showed a significant difference in student's critical thinking based on gender. They discovered that girls outperformed boys in critical thinking. Arslan further noticed that female students tend to use critical thinking skills in dealing with problems and situations related to the environment.

Olutola (2017) found that female students could outperform male students. However, Raheem (2012) revealed a difference in academic performance between boys and girls, where male students beat female students in science. Hill et al. (2010) stated that cognitive ability was one of the factors that could significantly affect gender inequality. It is found that male students have better spatial ability compared to female students. However, some other studies report that gender differences do not influence critical thinking (Verawati et al., 2010; Hunter et al., 2014). In a few studies, no difference was observed between male and female students' critical thinking scores. Aktamış and Yenice (2010), Shim and Walczak (2012), and Liu et al. (2019) reported that there was no correlation between gender 
and critical thinking skills. These assumptions provide a wide opportunity for researchers to conduct an in-depth study on the effect of gender on students' critical thinking skills.

The external factors that can influence students' critical thinking skills are educational paradigm, teaching approach and method, assessments' nature, teacher's feedback, emotional atmosphere, and positive attitude (Kaufman \& Beghetto, 2009; Shubina \& Kulakli, 2019). Besides these factors, school location (either rural or urban schools) can also affect students' critical thinking (Ramos et al., 2016; Huang et al., 2016; Darmaji et al., 2020). According to Ge and Wang (2019), there is a wide gap between rural and urban schools regarding education performance. Some factors that are considered the potential reasons urban students differ from rural students include family, availability of resources and technology, socioeconomic status, and teachers' quality (Ajai \& Imoko, 2013). Young (1998) states that urban schools are equipped with better facilities and resources than schools in rural areas. They differ in the quality of the teaching and learning process, teacher training, and school conditions. Tayyaba (2012) identifies several factors that influence the difference between rural and urban schools. These factors include the socioeconomic status and background of the student's family, the distance between the student's house and the school, the size of the classroom and the school, and the school's physical condition. The other factors are the availability of academic resources, the qualifications of the teachers, the teaching strategy applied in the classroom, the student's self-concept, the student's perception of the school's security, and supports from the parents and community. Rural and urban students also have distinct characteristics, such as cultural backgrounds, that can support or hinder their academic performance (Gray et al., 2005 as citing Opoku-Asare \& Siaw, 2015). According to Vygotsky (1978), the social environment will affect students' cognitive development.

It has become common to think that rural schools are considered inferior to urban schools (Fan \& Chen, 1999; Ajai \& Imoko, 2013; Alokan \& Arijesuyo, 2013; Faisal et al., 2016). Rural schools typically lack facilities compared to urban schools, and rural students rarely go to private courses. It is assumed that rural students receive more inadequate education than urban students, as illustrated in the deficit model theory of rural society (Fan \& Chen, 1999). However, rural students have more social capital benefits (Byun et al., 2012), such as their rural identity (Howley, 2006; Byun et al., 2012). Social capital that privileges rural students is the power that is often ignored by teachers and researchers (Howley, 2006). Besides, rural students have additional social support, such as unique experiences and closer relationships with the teachers and society (Byun et al., 2012). Social capital also, directly and indirectly, affects the students' personality development and academic achievement (Abrar-ul-haq et al., 2015). The students' cultural background may improve or impede their academic performance (Gray et al., 2005 as cited in Opoku-Asare \& Siaw, 2015). Bilgin and Eldeleklioğlu (2007) argue that critical thinking is influenced by learning experiences obtained from the surrounding environment. Another factor that also impacts rural students' critical thinking is society's 
awareness of how important education is to increase social status (Masitha \& Suprijono, 2016). Unlike urban students, rural students are more motivated to achieve good grades (Alokan \& Arijesuyo, 2013).

The difference in the rural and urban schools' characteristics implies a difference in the students' academic achievement (Faisal et al., 2016), including critical thinking skills. Young (1998) claims that urban and rural areas' distinct characteristics are the main cause of the students' different academic achievements. Ruralurban schools have different types of environments and climates that affect learning effectiveness (Opoku-Asare \& Siaw, 2015). Opoku-Asare and Siaw (2015) state that students from different cultural backgrounds will bring various prior knowledge and different learning resources into the classroom. Studies by Gamoran and Long (2006) and Behrman (2010) in developing countries show that school characteristics have a significant impact on student academic performance. There has been abundant research discussing the differences between rural-urban schools, but the results have not shown any consensus relating to these different characteristics' importance. Reeves and Bylund (2005), through repeated observations of HLM analysis, revealed that the annual performance achievement of rural schools was the same as or outperforming that of urban schools. Haller et al. (1993) and Fan and Chen (1999) found no significant difference between rural-urban schools' academic achievement. Tayyaba (2012) in the Northwestern Frontier Province (NWFP) of Pakistan reported that rural and urban students achieved the same science score. However, other research findings showed that urban schools obtained higher scores than rural schools (Young, 1998; Owoeye \& Yara, 2011; Maas et al., 2015). Ünsar and Engin (2013), Huang et al. (2016), and Darmaji et al. (2020) reported a difference between urban and rural students' critical thinking, where urban students had better critical thinking performance than rural students. These facts indicate that the relationship between school location and students' critical thinking skills needs to be further investigated.

Based on the aforementioned explanations in this study, previous studies on the role of gender and school location in the development of students' critical thinking skills showed different results. While some studies point out a difference between rural and urban students' critical thinking skills in terms of gender and school location, some others show that gender and school location do not affect students' critical thinking skills. Therefore, it is necessary to analyze how gender and school location affect students' critical thinking skills. To fill such a void, the present study was conducted to identify the difference in students' critical thinking according to gender differences and school location (e.g., rural and urban schools). This study's results are expected to provide an insight into the making of decisions by policymakers and teachers to empower students to think critically by considering gender differences and school location. 


\section{Method}

\section{Design}

The current study aimed to examine whether gender variables and school location affected students' critical thinking. For such a purpose, the study employed a quantitative approach with ex-post facto design.

\section{Participant Recruitment}

This study recruited 289 students from public and private schools based in urban and rural areas of East Java, Indonesia (see Table 1). They were recruited using a purposive random sampling method (Fraenkel et al., 2011). The students were then categorized based on gender and school location (rural-urban). Gender criteria were visualized on females and males, while school criteria were made based on school location.

Table 1

Sample Characteristics

\begin{tabular}{lccc}
\hline \multirow{2}{*}{ Gender } & & \multicolumn{2}{c}{$\mathbf{n = 2 8 9}$} \\
\cline { 3 - 4 } & Male & 118 & $\mathbf{0}$ \\
\hline \multirow{2}{*}{ School Location } & Female & 171 & 41 \\
& Urban & 178 & 59 \\
\hline
\end{tabular}

\section{Data collection}

Essays tests were used as the instrument to measure the students' critical thinking skills. The research instrument had undergone expert validation and empirical validation to check the construct validity in the essay questions. At this stage, experts were invited to give recommendations and advice for the instrument's quality improvement. Validity and reliability tests were also performed. The test reliability was measured using Cronbach's Alpha, while the test validity was examined using the Pearson correlation. Item validity was evaluated by finding the correlation between the score of each item and the total score. The correlation coefficient was obtained from the result of the correlation calculation. The correlation coefficient was used to measure item validity and determine whether the item would be used in this study or not. The validity and reliability tests showed that the instrument was valid and reliable (0.791). The results of the instrument validity test were summarized in Table 2 . 
Table 2

Results of the Instrument Validity Test

\begin{tabular}{cccc}
\hline Item & Pearson Correlation & Sig. (2-tailed) & Remarks \\
\hline 1 & 0.721 & .000 & Valid \\
2 & 0.779 & .000 & Valid \\
3 & 0.794 & .000 & Valid \\
4 & 0.760 & .000 & Valid \\
5 & 0.668 & .000 & Valid \\
\hline
\end{tabular}

The essay tests were conducted during lesson hours. Five essay questions should be completed within 50 minutes. The students' answers were assessed using a critical thinking rubric that was integrated into the essay tests. The rubric was a modification of Finken and Ennis (1993) which had been developed by Zubaidah et al. (2015) (Table 3).

Table 3

Critical Thinking Rubric Embedded in Essay Tests

\begin{tabular}{|c|c|}
\hline Score & Description \\
\hline 5 & $\begin{array}{l}\text { - All concepts are correct, clear, and specific } \\
\text { - All explanations of the answer are correct, clear, specific, supported by } \\
\text { strong and right reasons and clear arguments } \\
\text { - The way of thinking is good; all concepts are connected and integrated } \\
\text { - The grammar is good and correct } \\
\text { - All aspects are apparent; the evidence is good and balanced }\end{array}$ \\
\hline 4 & $\begin{array}{l}\text { - Most of the concepts are right, clear but less specific } \\
\text { - Most of the explanations of the answer are correct, clear but less specific } \\
\text { - The way of thinking is good, most of the concepts are correlated with } \\
\text { each other and integrated } \\
\text { - The grammar is good and correct; there are a few mistakes } \\
\text { - All aspects are apparent, but they are imbalanced }\end{array}$ \\
\hline 3 & $\begin{array}{l}\text { - A small part of the concepts are correct and clear } \\
\text { - A small part of the explanations of the answer are correct, clear but the } \\
\text { argument is unclear } \\
\text { - The way of thinking is good enough, a small part of the concepts are } \\
\text { correlated with each other } \\
\text { - The grammar is adequate; there are some errors in spelling } \\
\text { - Most of the apparent concepts are correct }\end{array}$ \\
\hline 2 & $\begin{array}{l}\text { - The concepts are less focused or exaggerating or doubting } \\
\text { - The explanations of the answer are not supporting } \\
\text { - The way of thinking is less appropriate; the concepts are not correlated } \\
\text { with each other } \\
\text { - The grammar is good; there are incomplete sentences } \\
\text { - A small part of the concepts looks right }\end{array}$ \\
\hline
\end{tabular}




\begin{tabular}{lll}
\hline Score & \\
\hline 1 & - & \multicolumn{1}{c}{ Description } \\
& - The reason is wrong \\
& - The way of thinking is poor \\
& - The grammar is poor \\
& - & Tll aspects are insufficient \\
\hline 0 & There is no answer, or the answer is wrong \\
\hline
\end{tabular}

\section{Data analysis}

The students' critical thinking difference based on gender differences and school location was measured using a t-test at a $5 \%$ significance level. Normality and homogeneity tests were conducted before testing the hypothesis. Kolmogorov-Smirnov was used to examine the data's normality, while the Levene test was used to investigate the data's homogeneity. The normality test results showed a $p$-value of 0.084 for gender and 0.081 for school location. The results of the homogeneity test showed $\mathrm{p}=0.181$ for gender and 0.300 for school location. Based on the analysis results, $p$-value $>\alpha(\alpha=0.05)$; this indicates that the data were distributed normally and homogeneously. The data were then analyzed using SPSS 23 for Windows.

\section{Findings}

The descriptive statistics of the students' critical thinking scores based on gender differences and school location can be seen in Table 4. The Table shows that the female students outperformed the male students in critical thinking with a $22.26 \%$ difference. The girls achieved a higher average score (50.85) than the boys (39.53). Similarly, the rural students had better critical thinking performance than the urban students with a $14.87 \%$ difference. The rural students obtained a higher average score (50.92) than the urban students (43.35). The research findings relating to gender differences indicated that there was a significant difference between male and female students' critical thinking scores $(p<0.05)$ (Table 4). Also, the results of the analysis of the school location showed that urban students differed significantly from rural students in critical thinking $(p<0.05)$ (Table 4).

\section{Table 4}

Critical Thinking Skills Based on Gender and School Location

\begin{tabular}{lccccccc}
\hline \multirow{2}{*}{ Gender } & & M & Std. Dev & Std. Err & df & t & P \\
& Male & 39.53 & 12.19 & 1.12204 & 287 & -7.155 & .000 \\
\hline \multirow{2}{*}{ School location } & Female & 50.85 & 13.90 & 1.06299 & & & \\
& Rural & 50.92 & 13.41 & 1.27260 & 287 & -4.493 & .000 \\
\hline
\end{tabular}




\section{Discussion}

\section{Gender differences in students' critical thinking skills}

The findings showed a significant difference between male and female students' critical thinking skills (Table 4). The female students outperformed the male ones in critical thinking by $22.26 \%$. The difference was clearly shown in the female students' detailed and complex answers, suggesting their excellent understanding of the problem. It was also due to the female students' language skills that are more developed than the male ones. Unlike the male students, the female students were more thorough and careful in answering the test questions. Therefore, female students had better critical thinking performance compared to male students.

This finding is confirmed by Halpern et al. (2007), who stated that women had more developed language skills compared to men. Furthermore, Arslan (2012) claims that women are more used to dealing with many problems, and therefore, become more detailed, more confident, and more flexible in thinking. Theoretically, some particular parts of the brain are responsible for language development. The frontal and temporal cortex in women have a significant volume and are well organized (Geary, 1998). The synaptic density in the female temporal neocortex is less than in males (Alonso-Nanclares et al., 2008) so that the female temporal cortex experiences specialization for language processing (Zaidi, 2010).

Besides, female students have better prior knowledge, more improved reading ability, and enhanced argumentative skills than boys. Students' prior knowledge has a significant influence on their critical thinking skills. Knowledge can be obtained through reading. Reading helps students obtain information from various resources. In this study, such knowledge was beneficial for the students to answer the essay tests. The students had to have a comprehensive understanding of the materials to answer the essay questions, which was reflected in the arguments provided in their answers. Mahapoonyanont (2012) has concluded that reading skills and argumentative skills can affect students' critical thinking skills. Some research findings also confirm that reading ability positively correlates with critical thinking (Hassani et al., 2013; Nasirahmadi, 2014).

The findings of this study are corroborated by the previous research by Arslan (2012), Mahanal (2012), Mouraz et al. (2014), and Kumar and James (2015), who argue that female students outperform male students in critical thinking. Further, Kumar and James revealed that girls have more developed argumentative skills than boys. Research by Oda and Abdul-Kadhim (2017) concluded that female students surpass male students in reading comprehension.

\section{Rural-urban school differences in students' critical thinking skills}

The present study showed a significant difference between rural and urban students' critical thinking skills (Table 4). It was found that rural students could outperform the 
urban students in critical thinking with a $14.87 \%$ difference. This finding suggests that the quality of education in rural areas is not inferior to urban areas' quality of education. It is assumed that the characteristics of the rural environment can affect the development of the rural students' critical thinking skills. Schools in rural areas have the privilege to receive social capital benefits from the close relationships between teachers and students and between school and society.

The student-teacher close relationships will help shape effective communication between them, which is key to improving education quality. The teacher-student closeness will also improve the students' achievement in learning, including critical thinking performance. This finding is corroborated by the previous research by Suarman (2015), who stated that the key factor in determining learning quality was the strong relationship between the teacher and the students. Moreover, Byun et al. (2012) note that rural students receive more advantages and support from their environment. The students have unique experiences, opportunity structures, and social construction as a powerful rural identity (Howley, 2006). Rural schools tend to maintain a family atmosphere, parental involvement, and school-society strong relationships (Hernández-Torrano, 2018). This study's findings are useful in understanding the benefits of social capital and other external factors that may impact student's learning achievement, including critical thinking performance. This study has found that social capital as a rural identity can be used as a foundation to strengthen education in rural schools.

The results of this study also confirm the previous findings by Haller et al. (1993), Fan and Chen (1999), and Ajai and Imoko (2013), who also highlight the excellence of the rural schools' performance compared to the urban schools' performance. This study has shown that rural students have no disadvantages in terms of the quality of education, confirming the research findings by Fan and Chen (1999) and Alokan and Arijesuyo (2013). Alokan and Arijesuyo further state that the rural benefit model can replace the rural deficit model. Therefore, education must have a newer and more objective perspective on rural students' performance.

Students' critical thinking skills are also influenced by individual factors, such as motivation and achievement needs. Rural students are more motivated than urban students. Alokan and Arijesuyo (2013) argue that rural students are more encouraged to get good grades than urban students. Parental support is also predicted as one of the reasons why rural students can outperform urban students. The rural society's awareness of the importance of education has risen in recent years. Many rural parents have been educated and aware that education is important for their children's academic success and future careers. A study by Masitha and Suprijono (2016) revealed that rural parents believe that they can provide their children with a better life and a better social status through education. Furthermore, Gang et al. (2019) concluded that parental support was a predictor of rural students' academic achievement. 


\section{Conclusions and Recommendations}

Based on the study results, it can be concluded that there is a difference in students' critical thinking skills in terms of gender and school location. The findings have revealed that female students could outperform male students in critical thinking. This can happen because female students acquire language faster than male students. When coming to the classroom, female students bring better prior knowledge and have better reading and argumentation abilities than male students. Similarly, rural students have better critical thinking performance compared to urban students. It thus indicates that the rural community's social capital can be a strong basis for the development of education in rural areas. The rural benefit model can be developed to replace the rural deficit model. Moreover, rural students need to be encouraged and made aware of the importance of education to improve their academic achievement.

It is recommended that teachers organize learning in such a way so that it can encourage students to develop their critical thinking skills. Besides that, teachers also need to consider gender equality in learning. It is also necessary to study the contribution of school resources and rural-urban society's social capital to the students' critical thinking skills. Similar research in the future needs to include demographic elements such as students' socioeconomic and cultural backgrounds as well as parent education.

\section{Acknowledgment}

We wish to thank the anonymous reviewers for this study for their insightful feedback on the earlier version of this paper.

\section{References}

Abrar-ul-haq, M., Akram, F., \& Farooq, R. M. A. (2015). The impact of social capital on educational attainment: evidence from rural areas of Pakistan. Research on Humanities and Social Sciences, 5(13), 95-102.

Ajai, J. T., \& Imoko, B. I. (2013). Urban and rural students' academic achievement and interest in geometry: a case-study with games and simulations method. Journal of Education Research and Production, 1(2), 56-63.

Aktamıs, H., \& Yenice, N. (2010). Determination of the science process skills and critical thinking skill levels. Procedia - Social and Behavioral Sciences, 2(2), 3282-3288. https://doi.org/10.1016/j. sbspro.2010.03.502 
Alokan, F. B., \& Arijesuyo, A. E. (2013). Rural and urban differential in student's academic performance among secondary school students in Ondo State, Nigeria. Journal of Educational and Social Research, 3(3), 213-217. https://doi.org/10.5901/jesr.2013.v4n3p213

Alonso-Nanclares, L., González-Soriano, J., Rodriguez, J. R., \& DeFelipe, J. (2008). Gender differences in human cortical synaptic density. Proceedings of the National Academy of Sciences, 105(38), 14615-14619. https://doi.org/10.1073pnas.0803652105

Arslan, S. (2012). The influence of environment education on critical thinking and environmental attitude. Procedia - Social and Behavioral Sciences, 55, 902-909. https://doi.org/10.1016/j. sbspro.2012.09.579

Bailin, S. (2002). Critical thinking and science education. Science \& Education, 11(4), 361-375. https://doi.org/10.1023/A:1016042608621

Behrman, J. R. (2010). Investment in education: Inputs and incentives. In D. Rodrik, \& M. R., Rosenzweig, (Eds.), Handbook of development economics: The economics of development polic, 5, (pp. 4883-4975). Amsterdam: North-Holland Publishing.

Bilgin, A., \& Eldeleklioğlu, J. (2007). An investigation into the critical thinking skills of university students. Hacettepe University Journal of Education, 33(33), 55-67.

Byun, S., Meece, J. L., Irvin, M. J., \& Hutchins, B. C. (2012). The role of social capital in educational aspirations of rural youth. Educational aspirations of rural youth. Rural Sociology, 77(3), 355-379. https://doi.org/10.1111/j.1549-0831.2012.00086.x

Carter, A. G., Creedy, D. K., \& Sidebotham, M. (2017). Critical thinking evaluation in reflective writing: Development and testing of carter assessment of critical thinking in midwifery (Reflection). Midwifery, 54, 73-80. https://doi.org/10.1016/j.midw.2017.08.00

Che, F. S. (2002). Teaching critical thinking skills in a Hongkong secondary school. Asia Pacific Education Review, 3(1), 83-91. https://doi.org/10.1007/BF03024923

Choi, K., Lee, H., Shin, N., Kim, S.-W., \& Krajcik, J. (2011). Re-conceptualization of scientific literacy in South Korea for the 21st century. Journal of Research in Science Teaching, 48(6), 670-697. https://doi.org/10.1002/tea.20424

Choy, S. C., \& Cheah, P. K. (2009). Teacher perceptions of critical thinking among students and its influence on higher education. International Journal of Teaching and Learning in Higher Education, 20(2), 198-206. (ERIC Document Reproduction Service No. EJ864337).

Corebima, A. D. (2016). Pembelajaran biologi di Indonesia bukan untuk hidup [Biology learning is not conducted for life in Indonesia]. Proceeding Biology Education Conference: Biology, Science, Environmental, and Learning, 13, 8-22.

Darmaji, D., Kurniawan, D. A., Astalini, A., Perdana, R., Kuswanto, K., \& Ikhlas, M. (2020). Do science process skills affect critical thinking in science? Differences in urban and rural. International Journal of Evaluation and Research in Education (IJERE), 9(4), 874-880. https:// doi.org/10.11591/ijere.v9i4.20687

Dowd, J. E., Thompson, R. J., Schiff, L. A., \& Reynolds, J. A. (2018). Understanding the complex relationship between critical thinking and science reasoning among undergraduate thesis writers. CBE - Life Sciences Education, 17(1), 4, 1-10, https://doi.org/10.1187/cbe.17-03-0052 
Ennis, R., H. (1996). Critical thinking. Upper Saddle River, New Jersey: Prentice-Hall.

Ennis, R., H. (2011). The nature of critical thinking: An outline of critical thinking dispositions and abilities. Retrieved August 29, 2018, from https://education.illinois.edu/docs/ default-source/faculty-documents/robert-ennis/thenatureofcriticalthinking 51711000. pdf?sfvrsn=7bb51288 2

Facione, P. (1990). Critical thinking: A statement of expert consensus for purposes of educational assessment and instruction. UpToDate. Retrieved August 11, 2019, from https://files.eric. ed.gov/fulltext/ED315423.pdf

Faisal, R., Shinwari, L., \& Mateen, H. (2016). Evaluation of the academic achievement of rural versus urban undergraduate medical students in pharmacology examinations. Asian Pacific Journal of Reproduction, 5(4), 317-320. https://doi.org/10.1016/j.apjr.2016.06.002

Fan, X., \& Chen, M., J. (1999). Academic achievement of rural school students: a multi-year comparison with their peers in suburban and urban schools. Journal of Research in Rural Education, 15(1), 31-46. (ERIC Document Reproduction Service No. ED418829).

Finken, M., \& Ennis, R., H. (1993). Illinois critical thinking essay test. Illinois: University of Illinois. Retrieved November 18, 2019, from http://criticalthinking.net/wp-content/uploads/2018/01/ IllCTEssayTestFinken-Ennis12-1993LowR-1.pdf]

Fisher, A. (2001). Critical thinking: An introduction. New York, NY 10011-4211, USA: Cambridge University Press.

Fong, C. J., Kim, Y., Davis, C. W., Hoang, T., \& Kim, Y. W. (2017). A meta-analysis on critical thinking and community college student achievement. Thinking Skills and Creativity, 26, 71-83. https://doi.org/ 10.1016/j.tsc.2017.06.002

Fraenkel, J. R., Wallen, N. E., \& Hyun, H. H. (2011). How to design and evaluate research in education. New York: McGraw-Hill Humanities/Social Sciences/Languages.

Gamoran, A., \& Long, D. A. (2007). Equality of educational opportunity: A 40-year retrospective. In R. Teese, S. Lamb, \& M. Duru-Bellat. (Eds.). International studies in educational inequality: Theory and policy, (pp. 23-47). Dordrecht: Springer. https://doi.org/10.1007/978-1-4020-5916-2_2

Gang, G. C. A., Han, C. G. K, \& Bansa, L. A. (2019). The contribution of psychological factors on academic achievement of rural students in the interior schools of Sabah division. International Journal of Education, Psychology and Counseling, 4(27), 76-90.

Ge, T., \& Wang, L. (2019). Multidimensional child poverty, social relationships and academic achievement of children in poor rural areas of China. Children and Youth Services Review, 103, 209-217. https://doi.org/10.1016/j.childyouth.2019.06.007

Geary, D. C. (1998). Male, female: The evolution of human sex differences. Washington, DC, US: American Psychological Association.

Haller, E., J., Monk, D., H., \& Tien, L., T. (1993). Small schools and higher-order thinking skills. Journal of Research in Rural Education, 9(2), 66-73.

Halpern, D. F., Benbow, C. P., Geary, D. C., Gur, R. C., Hyde, J. S., \& Gernsbacher, M. A. (2007). The science of sex differences in science and mathematics. Psychological Science in the Public Interest, 8(1), 1-51. https://doi.org/10.1111/j.1529-1006.2007.00032.x 
Hasan, S., Tumbel, F. M., \& Corebima, A. D. (2013). Empowering critical thinking skills in Indonesia archipelago: Study on elementary school students in Ternate. Journal of Modern Education Review, 3(11), 852-858.

Hassani, M. T, Rahmany, I., \& Babaei, M. (2013). The relationship between Iranian EFL learners' critical thinking and reading comprehension performance in journalistic texts. Theory and Practice in Language Studies, 3(10), 1873-1878. https://doi.org/10.4304/tpls.3.10.1873-1878

Hernández-Torrano, D. (2018). Urban-Rural excellence gaps: Features, factors, and implications. Roeper Review, 40(1), 36-45. https://doi.org/10.1080/02783193.2018.1393610

Hill, C., Corbett, C., \& Rose, A. (2010). Why so few? Women in science, technology, engineering, and mathematics. Washington, DC: American Association of University Women.

Howley, C. W. (2006). Remote possibilities: Rural children's educational aspirations. Peabody Journal of Education, 81(2), 62-80. https://doi.org/10.1207/S15327930pje8102 4

Huang, L., Zhao, X., Cai, Q., Su, N., Gan, Y., Xu, G. T., Fan, A. P. (2016). Examine the critical thinking capabilities of Chinese urban and rural medical students. Annals of Global Health, 82(3), 386. https://doi.org/10.1016/j.aogh.2016.04.628

Hunter, S., Pitt, V., Croce, N., \& Roche, J. (2014). Critical thinking skills of undergraduate nursing students: Description and demographic predictors. Nurse Education Today, 34(5), 809-814. https://doi.org/10.1016/j.nedt.2013.08.005

Iman, J. N., \& Angraini, N. (2019). Discussion task model in EFL classroom: EFL learners' perception, oral proficiency, and critical thinking achievements. Pedagogika, 133(1), 43-62. https://doi.org/10.15823/p.2019.133.3

Kaddoura, M. A. (2011). Critical thinking skills of nursing students in lecture-based teaching and case-based learning. International Journal for the Scholarship of Teaching \& Learning, 5(2), 1-18. https://doi.org/10.20429/ijsotl.2011.050220

Kaufman, J. C., \& Beghetto, R. A. (2009). Beyond big and little: The four C model of creativity. Review of General Psychology, 13(1), 1-12. https://doi.org/10.1037/a0013688

Khan, S. A. (2008). An experimental study to evaluate the effectiveness of cooperative learning versus traditional learning methods. [Unpublished doctoral dissertation.] Islamabad. Pakıstan: International Islamic University.

Kimura, D. \& Harshman, R. A. (1984). Sex differences in brain organization for verbal and non-verbal functions. In G. J. De Vries, J. P. C. De Bruin, H. B. M. Uylings, \& M. A Corner (Eds.), Sex differences in the brain: The relation between structure and function (pp. 423-441). Amsterdam: Elsevier.

Kumar, R. R., \& James, R. (2015). Evaluation of critical thinking in higher education in Oman. International Journal of Higher Education, 4(3). https://doi.org/10.5430/ijhe.v4n3p33

Larsson, K. (2017). Understanding and teaching critical thinking - A new approach. International Journal of Educational Research, 84, 32-42. https://doi.org/10.1016/j.ijer.2017.05.004

Liu, N.-Y., Hsu, W.-Y., Hung, C.-A., Wu, P.-L., \& Pai, H.-C. (2019). The effect of gender role orientation on student nurses' caring behaviour and critical thinking. International Journal of Nursing Studies, 89, 18-23. https://doi.org/10.1016/j.ijnurstu.2018.09.005 
Maas, T., Amolins, M., \& Vitiello, P. (2015). Science achievement in secondary school students across rural and urban South Dakota locales. South Dakota Medicine. The Journal of the South Dakota State Medical Association, 68(5), 197-199.

Mahanal, S. (2012). Strategi pembelajaran biologi, gender dan pengaruhnya terhadap kemampuan berpikir kritis [Biology learning strategy, gender and its effect on the potenstial of critical thinking skills]. Proceedings of Biology Education Conference: Biology, Science, Enviromental, and Learning, 9, 179-184.

Mahapoonyanonta, N. (2012). The causal model of some factors affecting critical Thinking abilities. Procedia - Social and Behavioral Sciences, 46, 146-150. https://doi.org/10.1016/j. sbspro.2012.05.084

Masita, P. N., Mahanal, S., \& Suwono, H. (2016). Critical thinking skills in biology learning class X senior high school. Research Report, (2), 539-545.

Masitha, D., \& Suprijono, A. (2016). Makna pendıdıkan formal bagı orang tua siswa di pulau Poteran [The meaning of formal education for parents on the Poteran Island]. Jurnal Paradigma, 4(1), 1-5.

Mawaddah, Ahmad, A., \& Duskri, M. (2018). Gender differences of mathematical critical thinking skills of secondary school students. Journal of Physics: Conference Series, 1088, 012054. https:// doi.org/10.1088/1742-6596/1088/1/012054

McCormick, N. J., Clark, L. M., \& Raines, J. M. (2015). Engaging students in critical thinking and problem solving: A brief review of the literature. Journal of Studies in Education, 5(4), 100. https://doi.org/10.5296/jse.v5i4.8249

Mortellaro, C. (2015). Exploring factors influencing critical thinking skills in undergraduate nursing students: A mixed-methods study. New Jersey: Seton Hall University.

Mouraz, A., Leite, C., Trindade, R., Ferreira, J.M.M., Faustino, A. M., \& Villate, J. (2014). Argumentative skills in higher education: A comparative approach. Journal of Education \& Human Development, 3(1), 279-299.

Nasirahmadi, A. (2014). The relationship between Iranian language learners' critical thinking ability and their reading comprehension achievement. International Journal of Research Studies in Language Learning, 3(7), 15-27. https://doi.org/10.5861/ijrsll.2014.689

Oda, A., H. \& Abdul-Kadhim, M. R. (2017). The relationship between gender and reading comprehension at college level. Journal of Basrah Research the Humanities Sciences, 42(6), $426-442$.

Olutola, A. T. (2017). School location and gender as predictors of students' performance in WASSCE multiple-choice test in biology. Liceo Journal of Higher Education Research, 12(1). https://doi.org/10.7828/liher.v12i1.960

Opoku-Asare, N. A. A., \& Siaw, A. O. (2015). Rural-urban disparity in students' academic performance in visual arts education: Evidence from six senior high schools in Kumasi, Ghana. SAGE Open, 5(4), 1-14. https://doi.org/10.1177/2158244015612523

Owoeye, J. S., \& Yara, P. O. (2011). School location and academic achievement of secondary school in Ekiti State, Nigeria. Asian Social Science, 7(5), 170-175. https://doi.org/10.5539/ass.v7n5p170 
Partnership for 21st Century Skills. (2009). Framework for 21st Century Learning. Retrieved November 18, 2018, from http://www.p21.org/storage/documents/P21 Framework.pdf

Raheem, B. O. A. (2012). The influence of gender on secondary school students' academic performance in South-West, Nigeria. Journal of Social Sciences, 31(1), 93-98. https://doi.org/ $\underline{10.1080 / 09718923.2012 .11893018}$

Ramos, R., Duque, J. C., \& Nieto, S. (2016). Decomposing the rural-urban differential in student achievement in Colombia using PISA microdata. Estudios de Economica Aplicada, 34(2), 379-412.

Reeves, E. B., \& Bylund, R. A. (2005). Are rural schools inferior to urban schools?A multilevel analysis of school accountability trends in Kentucky. Rural Sociology 70(3), 360-386. https:// doi.org/10.1526/0036011054831215

Repo, S., Lehtinen, T., Rusanen, E., \& Hyytinen, H. (2017). Prior education of Open University students contributes to their capability in critical thinking. Journal of Adult and Continuing Education, 23(1), 61-77. https://doi.org/10.1177/1477971417693416

Ruigrok, A. N. V., Salimi-Khorshidi, G., Lai, M.-C., Baron-Cohen, S., Lombardo, M. V., Tait, R. J., \& Suckling, J. (2014). A meta-analysis of sex differences in human brain structure. Neuroscience \& Biobehavioral Reviews, 39, 34-50. https://doi.org/10.1016/j.neubiorev.2013.12.004

Shakirova, D. M. (2007). Technology for the shaping of college students' and upper-grade students' critical thinking. Russian Education \& Society, 49(9), 42-52. http://doi.org/10.2753/ RES1060-9393490905

Shim, W., \& Walczak, K. (2012). The impact of faculty teaching practices on the development of students' critical thinking skills. International Journal of Teaching and Learning in Higher Education, 24(1), 16-30.

Shubina, I., \& Kulakli, A. (2019). Pervasive learning and technology usage for creativity development in education. International Journal of Emerging Technologies in Learning (IJET), 14(01), 95-109. https://doi.org/10.3991/ijet.v14i01.9067

Sternberg, R. J. (2002). Raising the achievement of all students: Teaching for successful intelligence. Educational Psychology Review, 14(4), 383-393. https://doi.org/10.1023/A:1020601027773

Suarman, S. (2015). Teaching quality and students' satisfaction: The intermediatory role of relationship between lecturers and students of the higher learning institutes. Mediterranean Journal of Social Sciences, 6(2), 626-632. https://doi.org/10.5901/mjss.2015.v6n2p626

Subiantoro, A., W., \& Fatkurohman, B. (2009). Kerampilan berpikir kritis siswa dalam pembelajaran biologi menggunakan media koran [Students' critical thinking skills in biology learning using newspaper media]. Jurnal Pendidikan Matematika Dan Sains, 14(2), 111-114.

Sulasih, Suparmi, A., \& Sarwanto. (2017). Profile of student critical thinking ability on static fluid concept. Journal of Physics: Conference Series, 909, 012060, 1-8. https://doi.org/10.1088/1742$\underline{6596 / 909 / 1 / 012060}$

Tayyaba, S. (2012). Rural-urban gaps in academic achievement, schooling conditions, student, and teachers' characteristics in Pakistan. International Journal of Educational Management, 26(1), 6-26. https://doi.org/10.1108/09513541211194356 
Tiruneh, D. T., De Cock, M., Weldeslassie, A. G., Elen, J., \& Janssen, R. (2017). Measuring critical thinking in physics: Development and validation of a critical thinking test in electricity and magnetism. International Journal of Science and Mathematics Education, 15(4), 663-682. https://doi.org/10.1007/s10763-016-9723-0

Ünsar, A. S., \& Engin, E. (2013). A case study to determine critical thinking skills of university students. Procedia - Social and Behavioral Sciences, 75, 563-569. https://doi.org/10.1016/j. $\underline{\text { sbspro.2013.04.061 }}$

Verawati, Arifin, S. R., Idris, R., \& Hamid, N. A. A. (2010). Gender analysis of MyCT (Malaysian Critical Thinking) Instrument. Procedia - Social and Behavioral Sciences, 7, 70-76. https:// doi.org/10.1016/j.sbspro.2010.10.011

Vygotsky, L. (1978). Mind in Society: The development of higher psychological processes. Cambridge, MA: Harvard University Press.

Wang, X., \& Zheng, H. (2016). Reasoning critical thinking: Is it born or made? Theory and Practice in Language Studies, 6(6), 1323-1331. https://doi.org/10.17507/tpls.0606.25

Wassell, J., Rogers, S. L., Felmingam, K. L., Bryant, R. A., \& Pearson, J. (2015). Sex hormones predict the sensory strength and vividness of mental imagery. Biological Psychology, 107, 61-68. https://doi.org/10.1016/j.biopsycho.2015.02.003

World Bank (2012). World Development Report 2012: Gender Equality and Development. Retrieved from https://openknowledge.worldbank.org/handle/10986/4391 License: CC BY 3.0 IGO.

Wood, J. T. (2008). Gendered lives: Communication, gender, and culture (8th ed). Belmont, CA: Thompson/Wadsworth.

Young, D. J. (1998). Rural and urban differences in student achievement in science and mathematics: A multilevel analysis. School Effectiveness and School Improvement, 9(4), 386-418. https://doi.org/10.1080/0924345980090403

Zaidi, Z. F. (2010). Gender differences in human brain: A review. The Open Anatomy Journal, 2, 37-55. https://doi.org/10.2174/1877609401002010037

Zubaidah, S., Corebima, A. D., Mistianah. (2015). Asesmen berpikir kritis tes essay [Critical Thinking assessment of essay test]. Proceeding of Symposium on Biology Education, Universitas Ahmad Dahlan, Yogyakarta, (pp. 200-213). Yogyakarta, Indonesia: Universitas Ahmad Dahlan. https://pbio.uad.ac.id/unduh/prosiding-symbion-2015 


\title{
Kaimo ir miesto skirtingos lyties mokinių kritinio mąstymo mokantis biologijos tyrimas
}

\author{
Badrud Tamam ${ }^{1}$, Aloysius Duran Corebima ${ }^{2}$, Siti Zubaidah ${ }^{3}$, Endang Suarsini ${ }^{4}$
}

1 Malango valstybinis universitetas, Biologijos mokymo katedra, Malangas, Rytų Javos provincija, Indonezija Trunojoyo Maduros universitetas, Gamtos mokslų studijų programa, Bangkalanas, Rytų Javos provincija, Indonezija, badruttamam@trunojoyo.ac.id

2 Kanjuruhano Malango universitetas, Gamtos mokslų mokymo programa, Malangas, Indonezija, durancorebima@gmail.com

3 Malango valstybinis universitetas, Biologijos mokymo katedra, Malangas, Rytų Javos provincija, Indonezija, siti.zubaidah.fmipa@um.ac.id

4 Malango valstybinis universitetas, Biologijos mokymo katedra, Malangas, Rytų Javos provincija, Indonezija, endang.suarsini.fmipa@um.ac.id

\section{Santrauka}

Indonezijoje atlikti išsamūs kritinio mąstymo tyrimai. Vis dèlto yra nedaug tyrimų, kuriuose aptariamas lyties poveikis mokinių kritiniam mąstymui. Manoma, kad dèl moterų ir vyrų smegenų struktūrų skirtumų lytis turi įtakos kritinio mąstymo raidai. Mokinių kritinis mąstymas mokyklos vietos atžvilgiu dar neatskleistas. Kaimo ir miesto mokyklos suteikia mokiniams skirtingą mokymosi aplinką, kuri gali paveikti jų kritinio mąstymo raidą. Šio tyrimo tikslas apibūdinti mokinių kritinio mąstymo ịgūdžių spragas, pagrịstas lytimi ir mokyklos vieta.

Atlikta kiekybinè, neeksperimentinè ex facto metodo analizè. Imties dydis - 289 bendrojo lavinimo valstybinių ir privačių mokyklų, esančių miesto ir kaimo vietovèse (Rytų Java, Indonezija), mokiniai. Tiriamieji buvo atrinkti taikant tikslinę atsitiktinę atranką (Fraenkel ir kt., 2011), o tada suskirstyti ị kategorijas pagal lytị ir mokyklos vietą (kaimo / miesto).

Siekiant ịvertinti mokinių kritinio mąstymo ịgūdžius, buvo kuriamas rašinio testas. Testo rezultatai buvo matuojami naudojant integruotą kritinio mąstymo rubriką, kuri buvo plètojama pagal Zubaidah ir kt. (2015) ir adaptuota pagal Finken \& Ennis (1993).

Rezultatai parodè, kad merginų kritinio mąstymo rodikliai geresni nei vaikinų, o kaimo mokiniai kritiškai mąstė geriau nei miesto mokiniai. Kita reikšminga išvada yra ta, kad kaimo mokyklų mokiniai lenkia miesto mokyklų mokinius. Todèl atsižvelgiant ị demografinius rodiklius labai svarbu patobulinti mokymo programą, suteikiančią lygias galimybes visiems mokiniams tiek vaikinams, tiek merginoms.

Esminiai žodžiai: kritinio mąstymo ịgūdžiai, lytis, kaimo mokyklos, miesto mokyklos. 